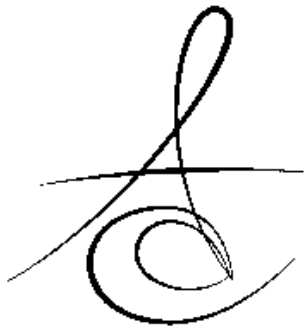

\title{
REMINERALIZATION AGENTS ON EARLY STAGE OF CARIES COMPARISON WITH DIFFERENT DIAGNOSTIC METHODS AND EVALUATE SURFACE HARDNESS OF REMINERALIZATION AREA
}

\section{BAŞLANGIÇ ÇÜRÜKLERİNDE REMİNERALİZE EDİCİ AJANLARIN ETKİSİNİN ÇEŞİTLİ DİAGNOSTIKK YÖNTEMLERLE KARŞILAŞTIRILMASI VE YÜZEY SERTLİKLERİNİN DEĞERLENDİRİLMESİ}

\author{
Uzm. Dt. Engin KARİPER* Doç. Dr. E. Gülşah GÖKTOLGA AKIN**
} Uzm. Dt. Oğuzhan ALICI ${ }^{* * *}$

Makale Kodu/Article code: 3785

Makale Gönderilme tarihi: 05.07.2018

Kabul Tarihi: 14.02 .2019

\begin{abstract}
ABSTRACAT
Aim: The aim of this study was to compare the extent of remineralization of permanent molar enamel with application of three remineralizing agents by employing QLF, microhardness and microcomputed tomography machine values.
\end{abstract}

Materials and Methods: An in vitro study was performed with 12 sound permanent molar teeth. The teeth were split in mesio-distal direction and two samples were obtained from each tooth $(n=8)$. An artificial caries lesion $(2 \times 4 \mathrm{~mm}$ ) was produced on enamel surfaces of sound molars using a previously reported demineralization model. Specimens were randomly divided into three groups: first group was treated using Tooth Mousse Plus (GC), the second group was treated using Clinpro Tooth Crème (3M ESPE) and the last group was treated using Sensodyne Protection and Repair (GSK). Demineralizing, remineralizing solutions and the tooth pastes were respectively applied the groups over a period of 14 days. The samples were subjected to QLF, microhardness, micro-computed tomography machine and electron microscope scanning.

Results: As compared with demineralization and remineralization values, in Tooth Mousse Plus group, micro-computed tomography showed no statistically significant difference $(p>0,05)$ but QLF and micro hardness machines showed statistically significant difference $(p<0,05)$. In Clinpro Tooth Crème and Sensodyne Repair and Protect groups; micro computed tomography, QLF and microhardness machines showed statistically significant difference $(p>0,05)$.

Conclusion: Tooth Mousse Plus, Clinpro Tooth Crème and Sensodyne Repair and Protection are appropriated means of treating caries at early stages.

Keywords: Reminalization, CPP-ACP, micro-computed tomography, microhardness, QLF

\section{öz}

Amaç: $\mathrm{Bu}$ çalışmanın amacı daimi molar dişlere uygulanan üç remineralize edici ajanın etkilerinin QLF, mikrosertlik ve milrobilgisayarlı tomografi cihazları ile elde edilen değerlerin karşılaştırılmasıdır.

Gereç ve yöntem: $\mathrm{Bu}$ in vitro çalışmada sağlam 12 adet daimi molar diş kullanıldı. Dişler mezio-distal yönde ikiye ayrıldı $(n=8)$. Yapay çürük lezyonu $(2 \times 4$ $\mathrm{mm}$ ) sağlıklı dişlerin minesinde demineralizasyon döngüsü ile oluşturuldu. Dişler rastgele 3 eşit gruba ayrıldı. 1. gruba Tooth Mousse Plus (GC), 2. gruba Clinpro Tooth Crème (3M ESPE) ve 3. gruba Sensodyne Onarım ve Koruma (GSK) uygulandı. 14 gün boyunca demineralizasyon, remineralizasyon solüsyonları ve diş macunları sırasıyla gruplara uygulandı. Numuneler QLF, mikrosertlik, mikrobilgisayarlı tomografi cihazları ile ölçüldü ve elektron mikroskobuyla değerlendirildi.

Bulgular: Tooth Mousse Plus uygulanan grupta demineralizasyon ve remineralizasyon değerleri kıyaslandığında, mikrobilgisayarlı tomografi istatistiksel olarak anlamlı bulunmamıştır ( $p>0,05)$ fakat QLF ve mikrosertlik cihazlarının değerleri istatistiksel olarak anlamlı bulunmuştur $(p<0,05)$. Clinpro Tooth Crème ve Sensodyne Onarım ve Koruma uygulanan gruplarda; mikrobilgisayarlı tomografi, QLF ve mikrosertlik değerleri istatistiksel olarak anlamlı bulunmamıştır ( $p>0,05)$.

Sonuç: Tooth Mousse Plus, Clinpro Tooth Crème ve Sensodyne Onarım ve Koruma erken dönem çürüklerin tedavisinde kullanılabilir.

Anahtar kelimeler: Remineralizasyon, CPP-ACP, mikrobilgisayarlı tomografi, mikrosertlik, QLF

\footnotetext{
* Edirne Ağız ve Diş Sağlığı Merkezi, Edirne

** Cumhuriyet Üniversitesi Diş Hekimliği Fakültesi Restoratif Diş Tedavisi AD, Sivas

*** Gaziantep Şahinbey Ağız ve Diş Sağlığı Hastanesi, Gaziantep
} 


\section{INTRODUCTION}

Dental caries are one of the most common and prevalent health problems among children and adults all around the world. ${ }^{17,23}$ The dentists therefore most frequently treat primary and secondary tooth cavities and renew previous restorations done on the teeth. ${ }^{36,11}$ The restorative therapy is costly and untreated caries cause chewing problems, pain (toothache) and life-long health problems. ${ }^{32}$ In recent years there has been a shift from invasive techniques to non-invasive ones in the field of dentistry. ${ }^{4}$ This may change the prevalence of caries in the population. ${ }^{22,25}$

In initial caries, most of the hydroxyapatite crystals which constitute the dental structure are seen to remain unaffected. The dental enamel is remineralized due to calcium, phosphate and flouride ions descending from the saliva. There are a number of theories on the fact that the dental enamel is more durable than the unaffected dental enamel. ${ }^{29}$

Several agents are utilized to remineralize the teeth. Some of them are in the following: caseine phosphopeptide amorph calcium phosphate, tricalcium phosphate, calcium sodium phosphosilicate. The caseine phosphopeptide is formed when caseine calcium and phosphopeptide accumulate as a result of triptic decomposition of milk protein and contains anticavity agent. ${ }^{33}$ The tricalcium phosphate is a form of calcium phosphate. It is formed when beta tricalcium phosphate and sodium lauric phosphate are combined. The tricalcium phosphate combine with flouride ion, providing more flouride and calcium ions to the surface of the enamel. It has been shown to cause remineralization on tooth enamel by both in vitro and in vivo studies. ${ }^{37}$ Calcium sodium phosphosilicate contains bioactive glass particles and was first used regenerate bones. It can be activated in mounth-oral fluids to remineralize the tooth. ${ }^{5}$

New methods have been developed to detect cavities in the mounth thanks to rapid changes in medical technologies. These include QLF, DİAGNOdent have started to be widely used in relation to the increases in dental caries. ${ }^{26}$

This study aims to compare the levels and effects of remineralization of various toothpaste that have remineralizing properties under $\mathrm{pH}$ cycle on the human molar teeth removed for several different reasons using QLF, microhardness and microcomputed tomography (MCT) devices.

\section{MATERIALS AND METHODS}

\section{Selection of the Research Sample}

12 human molar teeth without cavity and restoration which were extracted because of periodontal or orthodontic reasons were selected for the study. The sample teeth were preserved in $\% 1$ thymol solution for less than 3 months until the study was carried out. After the soft tissue residues and debris on the teeth had been cleared, the dental roots were cut $1 \mathrm{~mm}$ below cervical line using a seperator with low rotation.

\section{Preparation of the Sample}

The sample teeth were split in the center under watercooling using a seperator with low rotation in mesiodistal direction. Then two specimens were prepared from each tooth. The specimens were embedded with their buccal or palatinal surfaces upwards in an acrylic resin. The teeth were abrased using a sand paper of 600 grade and polisaged in order to prevent surface contamination and remove the hypermineralized structure on the surface. The buccal or palatinal surfaces of the specimen were left open in dimensions of $2 \times 4 \mathrm{~mm}$ and the other surfaces were covered by acid-resistant nail polish (Maybelline New York).

\section{Demineralization of the Sample}

The specimens were covered by acid-resistant varnish so as to make a window with the varnish and then demineralization solution was prepared to form primary cavity lesion. The demineralization solution consisted $1.5 \mathrm{mM}$ calcium chloride $\left(\mathrm{CaCl}_{2}\right), 0,9 \mathrm{mM}$ potassium-diphosphate $\left(\mathrm{KH}_{2} \mathrm{PO}_{4}\right), 50 \mathrm{mM}$ acetic acid $\left(\mathrm{CH}_{3} \mathrm{COOH}\right)$ and $3 \mathrm{mM}$ sodium nitride $\left(\mathrm{NaN}_{3}\right)$ and $\mathrm{pH}$ level was $4,8 .^{39}$ The specimens were stored in demineralization solution at $37^{\circ} \mathrm{C}$ in waterbath (Nuve BM 302, Ankara, Turkey) for 7 days. A specimen was randomly selected and the depth of lesion was examined by using micro-computed tomography device. Artificial cavities in the specimens were stored in $\% 100$ moisture settings. 


\section{Forming the groups}

Group 1: Caseinphosphopeptide-amorphous calcium phosphate (CPP-ACP) fluoride with GC Tooth Mousse Plus (TMP)

Group 2: Sodium fluoride-tricalcium phosphate (f-TCP) with Clinpro Tooth Creme (3M ESPE)

Groups 3: Novamine (calcium sodium phosphosilicate) with Sensodyne Repair and Protection

\section{Measuring Surface Microhardness (SMH) after demineralization}

The measurement of the specimens microhardness after demineralization was performed in Cumhuriyet University Faculty of Engineering, Department of Metallurgy and Materials laboratory using microhardness machine (Shimadzu HMV-M3 Kyoto, Japan), The specimens received $200 \mathrm{gr}$ force for 11 seconds with the tip of vickers diamond. The dentures formed on the demineralized windows were examined by using a microscope having a 40x magnifying power and calculated. The observers obtained results from four different zones of each specimen then the average values were recorded.

\section{Evaluating the cavity formation}

After the microhardness measurement was done, the demineralization valvues of the specimen were measured using QLF and MCT machines.

\section{Evaluation by QLF}

The QLF machine (QLF-D Biluminator 2, Amsterdam, The Netherlands) had a macrolens of Canon EFS $60 \mathrm{~mm}$ f/2,8 USM (Canon Inc. Japan) a Canon Camera (EOS 550D Model) and a biluminator. The biluminator had 12 blue LED lamps and 4 white strong LED lamps. The specimens were evaluated on an $x-y$ plane. Therefore, each specimen was measured at the same position. The specimens were washed and dried for 5 seconds before the procedure.

The QLF machine was fixed on the camera with an apparatus and the distance between the specimen and the lens was made stable. The specimens were measured and evaluated in the dark. The average fluorescence demineralization loss in the specimens was calculated using $(\% \Delta \mathrm{F}) \mathrm{QA2}$ version 1.18.

\section{Evaluation by Micro Computed Tomography}

Dental crowns were fixed in falcon tubes in the sample chamber on MCT device. The dental crowns were scanned via SkyScan 1172 on MCT device.

The device was calibrated for the procedure with the following settings: $100 \mathrm{kV}, 100 \mathrm{~mA}, 8,5$ pixel size, 0,4 rotational steps average imaging quality (as the number of frames) 3 and one images/1300 milliseconds. Each tooth was scanned for 99 minutes. The coronal images of the teeth were saved as TIFF image format. The images obtained were converted to make coronal fractions using NRecon Software (version1.6.5.2).

After this procedure, dental fraction images of each specimen were sawed as bitmag file. The coronal, sagittal and axial fractions of the images were examined to find out defects on the teeth by using Data Viewer Software (version 1.5.1, Skyscan, Kontich, Belgium) and evaluated on the computer by the observers.

\section{Remineralization of the Samples}

pH cycle was applied to the samples to imitate the dynamic milieu in the mounth after creating primary cavity lesion. The $\mathrm{pH}$ cycle consists of demineralizing agents that represent acid attacks in the mouth (Calcium2,0 mM, phosphate 2,0 mM, acetic acid $75,0 \mathrm{mM}, \mathrm{pH} 4,4)$ and remineralizing agents that represent the remineralizing effect of the saliva $(1,5$ $\mathrm{mmol} / \mathrm{l} \mathrm{Ca++}, 0,9 \mathrm{~mol} / \mathrm{l}$ phosphate, $130 \mathrm{mmol} / \mathrm{l}$ potassium chloride and $100 \mathrm{mmol} / \mathrm{l}$ tris tampon buffer, $\mathrm{pH} \mathrm{7,0).}$

The toothpastes were stirred with $1 / 3$ ratio water for 4 minutes $(1 \mathrm{ml}$ of therapeutic agent and 3 $\mathrm{ml}$ of water). After the samples were washed in deionized water, they were immersed into the mixture of $1 / 3$ ratio water and $4 \mathrm{ml}$ of toothpaste for 1 minute. Then they were washed with deionized water again. The samples were left in demineralization solition at $37^{\circ} \mathrm{C}$ for 6 hours so that each samples could have 40 $\mathrm{ml}$ of demineralization solution. After the procedure the samples were washed with deionized water and the mixture prepared before (1/3 ratio of water and toothpaste) was applied to the samples for 1 minute again. After being washed with deionized water again,

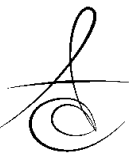


the samples were left in remineralization solution for 17 hours at night. The remaining one hour was spent by preparing the mixture and appling it to the sample. The procedure lasted 14 days. The remineralization solution was changed every two days and the demineralization solution was changed every five days. $^{34}$

Table 1. pH cycle

\begin{tabular}{|l|l|}
\hline Treatment & Time \\
\hline Washing with deionized water & \\
\hline $\begin{array}{l}\text { 1.Tooth paste aplication and washing } \\
\text { with deionized water }\end{array}$ & 1 minute \\
\hline Demineralization & 6 hour \\
\hline Washing with deionized water & 1 minute \\
\hline $\begin{array}{l}\text { 2. Tooth paste aplication and washing } \\
\text { with deionized water }\end{array}$ & 17 hour \\
\hline Mineralization &
\end{tabular}

\section{Microhardness measurement after application}

The measurements of surface microhardness were done using vickers hardness testing after the $\mathrm{pH}$ cycle. The samples were measured from their 4 different demineralized zones. The avarage values were evaluated and recorded by the observers.

\section{Evaluation of Remineralization}

After the $\mathrm{pH}$ cycle performed the samples were measured again using QLF and micro computed tomography. The samples were left in deionized water for a week after the evaluation to show the consistency of the measurements. When the measurements showed consistency, the study continued.

\section{Scanning Electron Microscope (SEM)}

The remineralized surfaces were examined by scanning electron microscope (LEO 440 Computer Controlled Digital, UK). The Samples were placed on the metal holder using adhesive double layered selotapes and then fixed on the proposion machine. Here the vacummed samples were covered in gold. After the surfaces were entirely covered in gold, the samples were ready to be examined. Then the samples were examined using SEM working on $20 \mathrm{kV}$ filamenttension under 150 millitorr low vacuum. The examined surfaces were photograped to obtain X 1000 and X 2000 sized images.

\section{Statistical Methods}

The findings of the study were analyzed in Cumhuriyet University, Faculty of Medicine, Department of Biostatistics. The data were analyzed by using SPSS (version 22) Paramentrical assumptions couldn't be verified, so Mann-Whitney Utest, KruskallWallis test and Mc Neman test were used. The eror level was determined as $p=0,05$.

\section{RESULTS}

\section{Remineralization and Demineralization Value of the Groups}

The values in Table 2 were compared to each other QLF, SMH and MCT values were statistically significant.

The values in Table 3 were compared to each other, QLF, SMH and MCT values were statistically signicant.

The values in Table 4 were compared to each other, QLF, SMH and MCT values were statistically significant.

Table 2. Demineralization and remineralization values of the group treated by tooth mousse plus.

\begin{tabular}{|l|l|l|l|}
\hline Groups & Demineralization & Remineralization & $\mathbf{p}$ \\
\hline QLF & $-24,53 \pm 6,62^{\mathrm{a}}$ & $-10,61 \pm 3,43^{\mathrm{b}}$ & 0,001 \\
\hline SMH & $72,87 \pm 30,53^{\mathrm{a}}$ & $134,62 \pm 26,37^{\mathrm{b}}$ & 0,001 \\
\hline MCT & $150,75 \pm 77,99^{\mathrm{a}}$ & $80,62 \pm 28,11^{\mathrm{b}}$ & 0,047 \\
\hline \multicolumn{2}{|l}{ Each column shows statistical differences with different }
\end{tabular}
letters $(p<0,005)$.

Table 3. Demineralization and remineralization values of the group treated by Clinproo Tooth Creme.

\begin{tabular}{|l|l|l|l|}
\hline Groups & Demineralization & Remineralization & p \\
\hline QLF & $-14,60 \pm 7,06^{\mathrm{a}}$ & $-10,87 \pm 4,30^{\mathrm{b}}$ & 0,023 \\
\hline SMH & $94,25 \pm 56,38^{\mathrm{a}}$ & $136,12 \pm 61,43^{\mathrm{b}}$ & 0,048 \\
\hline MCT & $133,62 \pm 47,09^{\mathrm{a}}$ & $82,62 \pm 43,05^{\mathrm{b}}$ & 0,038 \\
\hline
\end{tabular}

Each line shows statistical differences with different letters $(p<0,005)$. 
Table 4. Demineralization and remineralization values of the group treated by Sensodyne Repair and Protection.

\begin{tabular}{|l|l|l|l|}
\hline Groups & Demineralization & Remineralization & $\mathbf{p}$ \\
\hline QLF & $-43,00 \pm 64,05^{\mathrm{a}}$ & $-10,18 \pm 5,86^{\mathrm{b}}$ & 0,012 \\
\hline SMH & $63,87 \pm 20,27^{\mathrm{a}}$ & $110,88 \pm 41,56^{\mathrm{b}}$ & 0,042 \\
\hline MCT & $163,25 \pm 57,91^{\mathrm{a}}$ & $84,75 \pm 23,89^{\mathrm{b}}$ & 0,002 \\
\hline
\end{tabular}

Each line shows statistical differences with different letters. $(p<0,005)$

\section{Examination of SEM images}

The evaluation of the SEM images showed that dentine tubules were highly clogged and had created accumulations indicating remineralization in all three groups.

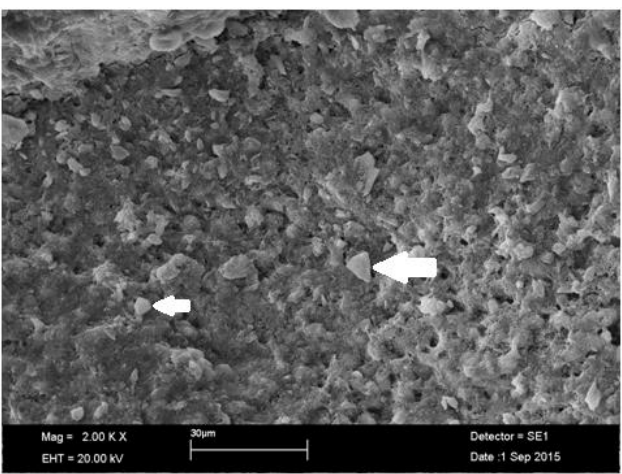

Figure 1 . The image of sample under SEM randomly chosen from the group 1 (GC Tooth Mousse Plus) with x2000 times magnified state.

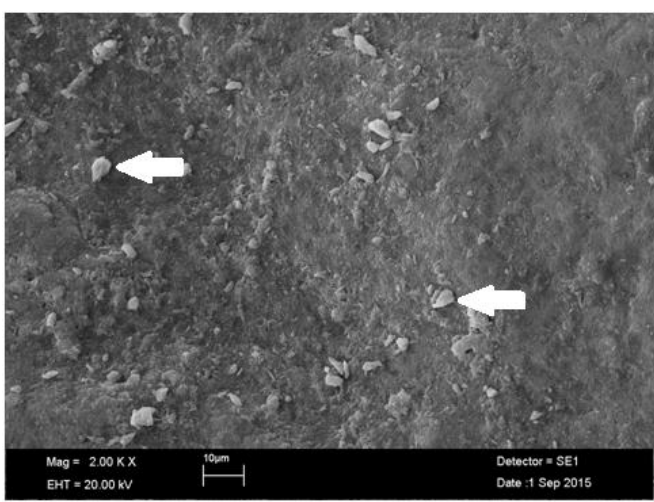

Figure 2. The image of sample under SEM randomly chosen from the group 2 (Clinpro Tooth Creme) with x2000 times magnified state.

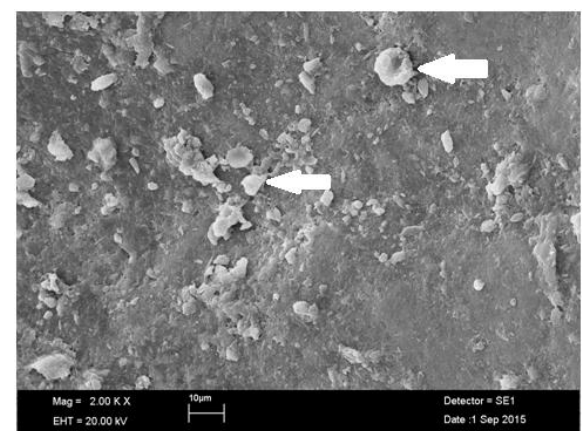

Figure 3. The image of sample under SEM randomly chosen from the group 3 (Sensodyne Repair and Protection) with x2000 times magnified state.

\section{MCT Images}

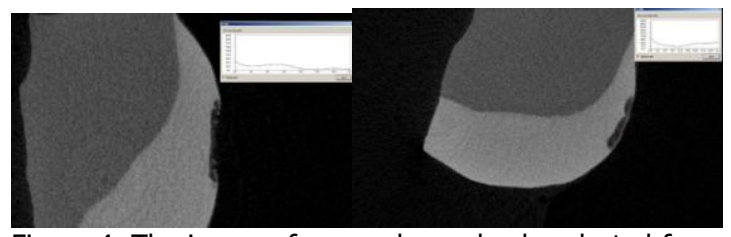

Figure 4. The image of a sample randomly selected from the group 1 (GC Tooth Mousse Plus) in demineralization (on the left) and the image of the same sample after remineralization on MCT.

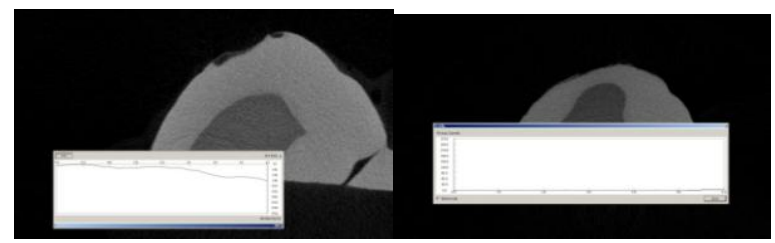

Figure 5. The image of a sample randomly selected from the group 2 (Clinpro Tooth Creme) in demineralization (on the left) and the image of the same sample after remineralization on MCT.

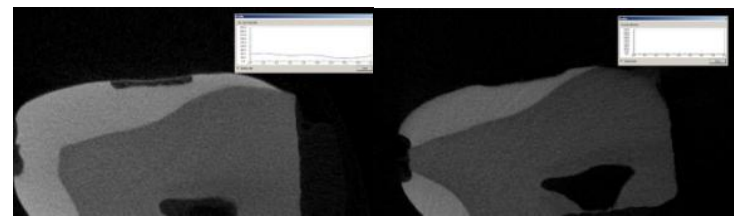

Figure 6 . The image of a sample randomly selected from the group 3 (Sensodyne Repair and Protection) in demineralization (on the left) and the image of the same sample after remineralization on MCT.

According to MCT images the demineralized areas seemed to use remineralize.

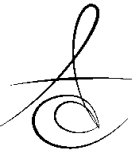




\section{DISCUSSION}

Minimally invasive dentistry is to prevent the progression of the underlying disease and to protect the dental tissue. In the past century, dentists based on G.V. Black's principles, they have formed cavities according to the rule of 'expand to protect'. According to this view, all demineralised areas of the dental tissue should be removed and filled with restorative material. However, this concept causes the loss of the coronal structure during the restoration. For this reason, nowadays, minimally invasive technique is increasingly used. ${ }^{8}$

The most appropriate method for examining the efficacy of remineralization agents used in the non-invasive treatment of initial caries lesions is the inability to be in vivo experiments, the high number of participants, the long duration of the study, the persistence of participants and the ethical reasons constitute the main difficulties of these studies. The advantages of in vitro studies are that they are highly controlled, have fewer variations and can be selected for small samples. ${ }^{9}$ So in our study we choosed in vitro study model to make lower mistake.

The parameters for in vitro studies should be carefully selected, while the criteria for tooth retention, tooth retention times, initial demineralization process, imitation of the oral environment, and remineralization criteria should be carefully selected. ${ }^{16}$

When the efficacy of the remineralizing agents is tested, in vitro studies using bovine or human enamel. There are some differences between bovine and human enamel. Bovine enamel is more rough, soft, more carbonated and contains less fluoride than human enamel. Moreover, the arrangement of the prisms in the lower third quadrant of the minerals is different, the crystals are larger in bovine, but the prisms are smaller in diameter. ${ }^{13}$ In this study, human enamels were used to obtain closer data to the correct results.

The artificial caries solutions used to form the initial caries differ in the studies carried out. The mean duration of treatment varies from $\mathrm{pH}$ 4-5 to 32 hours to 8 weeks. ${ }^{19,24,7,1,2}$ This difference in demineralization times causes differences in the caries lesions that occur. As a result of the demineralization carried out in a short time, soft erosion-like structures occur on the surface of the enamel. That lesions are different from initial lesions. Long-term demineralization causes more like the initial caries lesions that occurs in vivo conditions. This affects the content of demineralization solution, $\mathrm{pH}$ and demineralization duration. ${ }^{6}$ In our study, we stored the samples in demineralization solution with $\mathrm{pH}=4.8$ for 7 days to form the initial lesion. So we planned to make long term demineralization to make more closer initial caries lesions that occurs in in vivo condidions.

The $\mathrm{pH}$ cycle has been used for many years in in vitro studies to imitate the dynamic environment of the mouth and to create a caries, which histologically similar to the oral environment. ${ }^{38,28,15,18}$ In our study we make 14 days $\mathrm{pH}$ cycle. This cycle help us to make closer results. Our mineralization time is 17 hour this simulate salivas mineralization on teeth while sleeping or not eating or drinking. Demineralization time is 6 hours which is simulate acid attacs while eating and drinking.

Reynolds et al. argued that the effect of the fluorides used in the treatment of initial caries lesions during demineralization was sufficient in the presence of free calcium and phosphate ions in the environment. ${ }^{27}$ We used fluoride-containing toothpastes that contain calcium and phosphate ions that we use in our work.

The first step of our study is the comparison of the effects of different remineralizing agents on the initial caries. In our study, we used group 1 Tooth Mousse Plus (GC), group 2 Clinpro Tooth Creme (3M espe), and group 3 Sensodyne Repair and Protection (GSK) as remineralizing agents. In a study by Elkassas et al. found that a toothpaste with triple calcium phosphate ions with $5 \%$ sodium fluoride formed a protective barrier in which fluoride and calcium coexisted during application to the tooth surface, after which they were attacked with calcium and fluoride ions. ${ }^{10}$ In our study, we found the remineralizing effect of tricalcium phosphate-containing toothpaste to be statistically significant. Balakrishnan et al. have shown that the remineralizing effect of CPP-ACP is shown in in situ and long-term controlled randomized in vivo studies. This remineralizing effect is explained by the release of free calcium and phosphate ions from the ACP on the tooth surface and the supersaturation of the miner. ${ }^{3}$ Shen et al. found that Clinpro contained sodium fluoride ions but that their 
bioavailability was low when calcium ions and phosphate ions were added without stabilizer. In addition, calcium and phosphate ions in normal saliva have been shown to be limiting for continuous remineralization of subsurface lesions of the navel when applied topical fluoride. ${ }^{30}$ In vitro studies by Shetty et al. have shown that CPP-ACP increases effective remineralization in enamel lesions with initial decay according to the results obtained in vickers surface hardness measurements obtained before and after treatment. However, compared to fluoridesupplemented CPP-ACP and NaF, efficacy is less. Fluoride-associated CPP-ACP was the most effective group followed by $\mathrm{NaF}^{31}$

Mohanty et al., the clinical use of calcium and phosphate ions for remineralization was unsuccessful, suggesting that calcium and phosphate ions are difficult to dissolve and that 10 calcium and 6 phosphate ions should be present in the environment despite both fluoride ions. Nevertheless, novaminin is a bioactive glass molecule that is highly biocompatible and has been produced for bone regeneration. When they come together with body fluids, they point out that this molecule is converted to hydroxycarbonate apatite (HCA) which is close to the hydroxyapatite crystal in the structure of enamel and dentin, and that it provides remineralization. ${ }^{21}$

In the vast majority of these studies, the demineralization values of the groups treated with toothpaste were significantly higher than the remineralization values. In our study, the remineralization values of toothpastes that we applied to groups during the $\mathrm{pH}$ cycling were large and statistically significant in terms of demineralization values in accordance with the above studies. Gomez et al. reported that the agreement between fluoride dose response and QLF and surface hardness measurements was found to be statistically significant. ${ }^{12}$ In our study, the difference between the groups with microhardness and QLF instruments was found to be statistically insignificant if vickers diamond tip was used.Mitropoulos et al. reported that ICDAS II visual inspection criteria and MCT are more compatible values, digital radiography and conventional radiography systems are comparable to each other and less compatible than other methods compared to the histological section of the rotator cuff. ${ }^{20}$ Lo et al. argued that MCT could be used instead of polarised light migroscope and transverse microradiography in in vitro studies on caries. ${ }^{14}$ Soviero et al. MCT has been reported to show very high compliance when compared with histological examination. It has also been reported that compared to other methods of caries detection used in the study, both the enamel and dentin decay depth are better in diagnostic efficiency and that can be used as gold standard in the detection of interface decay. ${ }^{35}$

\section{CONCLUSIONS}

The remineralizing effect of Tooth Mousse Plus (GC), Clinpro Tooth Creme (3M ESPE) and Sensodyne Repair and Protection (GSK) toothpastes on initial caries was sufficient. The efficacy of MCT, SMH and QLF devices in evaluating initial caries in vitro conditions was sufficient. Our study shows that both tooth pastes can be used in white spot lesions and early stages of caries.

Engin Kariper: ORCID ID: 0000-0001-8196-6760 E. Gülşah Göktolga Akın: ORCID ID: 0000-0001-91834032

Oğuzhan Alıcı:ORCID ID: 0000-0001-5854-6805

\section{REFERENCES}

1. Alhawij $\mathrm{H}$, Lippert $\mathrm{F}$, and Martinez-Mier EA. Relative fluoride response of caries lesions created in fluorotic and sound teeth studied under remineralizing conditions. J Dent 2015;43:103-9.

2. Amaechi BT and Ramalingam K. Evaluation of fluorescence imaging with reflectance enhancement technology for early caries detection. Am J Dent 2014; 27: 111-6.

3. Balakrishnan $A$, Jonathan $R$, Benin $P$, and Kuumar A. Evaluation to determine the caries remineralization potential of three dentifrices: An in vitro study. J Conserv Dent 2013;16: 375-9.

4. Borsatto MC, Corona SA, Dibb RG, Ramos RP, and Pecora JD. Microleakage of a resin sealant after acid-etching, Er:YAG laser irradiation and airabrasion of pits and fissures. J Clin Laser Med Surg 2001; 19: 83-7.

5. Burwell AK, Litkowski LJ, and Greenspan DC. Calcium sodium phosphosilicate (NovaMin): remineralization potential. Adv Dent Res 2009; 21 : 35-9. 
6. Buzalaf MA, Hannas AR, Magalhaes AC, Rios D, Honorio HM, and Delbem AC. pH-cycling models for in vitro evaluation of the efficacy of fluoridated dentifrices for caries control: strengths and limitations. J Appl Oral Sci, 2010; 18:316-334.

7. Cochrane NJ, Walker GD, Manton DJ, and Reynolds EC. Comparison of quantitative light-induced fluorescence, digital photography and transverse microradiography for quantification of enamel remineralization. Aust Dent J 2012; 57:271-6.

8. Dalli M, Colak H, and Mustafa Hamidi M. Minimal intervention concept: a new paradigm for operative dentistry. J Investig Clin Dent 2012; 3: 167-75.

9. De Munck J, Van Landuyt K, Peumans M, Poitevin A, Lambrechts P, Braem M, and Van Meerbeek B. A critical review of the durability of adhesion to tooth tissue: methods and results. J Dent Res 2005; 84:118-32.

10. Elkassas D and Arafa A. Remineralizing efficacy of different calcium-phosphate and fluoride based delivery vehicles on artificial caries like enamel lesions. J Dent 2014;42:466-74.

11. Forss $\mathrm{H}$ and Widstrom $\mathrm{E}$. Reasons for restorative therapy and the longevity of restorations in adults. Acta Odontol Scand 2004;62:82-6.

12. Gomez J, Pretty IA, Santarpia RP, 3rd, Cantore B, Rege A, Petrou I, and Ellwood RP. Quantitative light-induced fluorescence to measure enamel remineralization in vitro. Caries Res 2014; 48: 2237.

13. Lippert F and Juthani K. Fluoride dose-response of human and bovine enamel artificial caries lesions under pH-cycling conditions Clin Oral Investig 2015;19: 1947-54.

14. Lo EC, Zhi QH, and Itthagarun A. Comparing two quantitative methods for studying remineralization of artificial caries. J Dent 2010; 38: 352-9.

15. Lv X, Yang Y, Han S, Li D, Tu H, Li W, Zhou X, and Zhang $L()$. Potential of an amelogenin based peptide in promoting reminerlization of initial enamel caries. Arch Oral Biol 2015;60:1482-7.

16. Lynch RJ. Model parameters and their influence on the outcome of in vitro demineralisation and remineralisation studies. Monogr Oral Sci 2006; 19: 65-85.
17. Marcenes W, Kassebaum NJ, Bernabe E, Flaxman A, Naghavi M, Lopez A, and Murray CJ. Global burden of oral conditions in 1990-2010: a systematic analysis. J Dent Res 2013; 92:592-7.

18. Malekafzali B, Ekrami M, Mirfasihi A, and Abdolazimi Z. Remineralizing Effect of Child Formula Dentifrices on Artificial Enamel Caries Using a pH Cycling Model. J Dent (Tehran) 2015;12:11-7.

19. Mehta R, Nandlal B, and Prashanth S. Comparative evaluation of remineralization potential of casein phosphopeptide-amorphous calcium phosphate and casein phosphopeptide-amorphous calcium phosphate fluoride on artificial enamel white spot lesion: an in vitro light fluorescence study. Indian J Dent Res 2013;24:681-9.

20. Mitropoulos P, Rahiotis C, Stamatakis $H$, and Kakaboura A. Diagnostic performance of the visual caries classification system ICDAS II versus radiography and micro-computed tomography for proximal caries detection: an in vitro study. J Dent 2010;38:859-67.

21. Mohanty P, Padmanabhan S, and Chitharanjan AB. An in Vitro Evaluation of Remineralization Potential of Novamin((R)) on Artificial Enamel Sub-Surface Lesions Around Orthodontic Brackets Using Energy Dispersive X-Ray Analysis (EDX). J Clin Diagn Res 2014;8: ZC88-91.

22. Newbrun E. Preventing dental caries: breaking the chain of transmission. J Am Dent Assoc 1992; 123: 55-9.

23. Nithila $A$, Bourgeois $D$, Barmes DE, and Murtomaa H. WHO Global Oral Data Bank, 1986-96: an overview of oral health surveys at 12 years of age. Bull World Health Organ 1998;76:237-44.

24. Oliveira GM, Ritter AV, Heymann HO, Swift E, Jr., Donovan T, Brock $G$, and Wright $T$. Remineralization effect of CPP-ACP and fluoride for white spot lesions in vitro. J Dent 2014; 212:1592602.

25. Pardi V, Sinhoreti MA, Pereira AC, Ambrosano GM, and Meneghim Mde C. In vitro evaluation of microleakage of different materials used as pitand-fissure sealants. Braz Dent J 2006;17:49-52.

26. Pretty IA, Edgar WM and Higham SM. A review of the effectiveness of quantitative light-induced fluorescence (QLF) to detect early caries. Early Detection of Dental Caries III: Proceedings of the

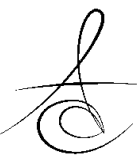


6th Indiana Conference. Indianapolis, Ind: Indiana University School of Dentistry, 2003.

27. Reynolds EC. Calcium phosphate-based remineralization systems: scientific evidence? Aust Dent J 2008; 53:268-73.

28. Rirattanapong $P$, Vongsavan $K$, Saengsirinavin C, and Pornmahala T. Effect of Fluoride Varnishes Containing Different Calcium Phosphate Sources on Mineralization of Initial Primary Enamel Lesions. Southeast Asian J Trop Med Public Health 2014; 45: 1503-10.

29. Roberson TM HH, Swift EJ. Sturdevant's Art and Science of Operative Dentistry. 5 ed. St.Louis: Mosby Co. 2011: 67-134.

30. Shen P, Manton DJ, Cochrane NJ, Walker GD, Yuan Y, Reynolds C, and Reynolds EC. Effect of added calcium phosphate on enamel remineralization by fluoride in a randomized controlled in situ trial. J Dent, 2011; 39:518-25.

31. Shetty S, Hegde MN, and Bopanna TP. Enamel remineralization assessment after treatment with three different remineralizing agents using surface microhardness: An in vitro study. J Conserv Dent 2014; 17:49-52.

32. Soderstrom U, Johansson I, and SunnegardhGronberg K. A retrospective analysis of caries treatment and development in relation to assessed caries risk in an adult population in Sweden. BMC Oral Health 2014; 14:126.

33. Somasundaram $P$, Vimala N, and Mandke LG. Protective potential of casein phosphopeptide amorphous calcium phosphate containing paste on enamel surfaces. J Conserv Dent 2013;16:152-6.

34. Soviero VM, Leal SC, Silva RC, and Azevedo RB. Validity of MicroCT for in vitro detection of proximal carious lesions in primary molars. J Dent 2012; 40:35-40.

35. Stookey GK, Featherstone JD, Rapozo-Hilo M, Schemehorn BR, Williams RA, Baker RA, Barker ML, Kaminski MA, McQueen CM, Amburgey JS, Casey $\mathrm{K}$, and Faller RV. The Featherstone laboratory $\mathrm{pH}$ cycling model: a prospective, multisite validation exercise. Am J Dent 2011;24:322-8.

36. Sunnegardh-Gronberg K, van Dijken JW, Funegard $U$, Lindberg A, and Nilsson M. Selection of dental materials and longevity of replaced restorations in Public Dental Health clinics in northern Sweden. ] Dent 2009; 37: 673-8.
37. Vanichvatana $S$ and Auychai P. Efficacy of two calcium phosphate pastes on the remineralization of artificial caries: a randomized controlled doubleblind in situ study. Int J Oral Sci 2013; 5: 224-8.

38. Wierichs RJ, Zelck $H$, Doerfer CE, Appel $P$, Paris $S$, Esteves-Oliveira $M$, and Meyer-Lueckel $H$. Effects of dentifrices differing in fluoride compounds on artificial enamel caries lesions in vitro. Odontology 2017; 105: 36-45.

39. Zhang $X$, Li $Y$, Sun $X$, Kishen A, Deng $X$, Yang $X$, Wang $H$, Cong $C$, Wang $Y$, and Wu $M$. Biomimetic remineralization of demineralized enamel with nano-complexes of phosphorylated chitosan and amorphous calcium phosphate. J Mater Sci Mater Med 2014; 25: 2619-28

\section{Yazışma Adresi}

Oğuzhan ALICI

Gaziantep Şahinbey Ağız ve Diş Sağlığı

Hastanesi, Gaziantep

Tel: 0 (346) 21910 10/2791

Fax: 0 (346) 2191237

E-mail: oguzhanalici06@gmail.com 